\title{
Japanese Vocabulary Acquisition Through Anime: A Case Study On Dwimeilinda
}

\author{
Virgi Marlany Ibnatul Karimah*, Fahriany, Firdaus Habibi \\ Syarif Hidayatullah State Islamic University of Jakarta, Indonesia \\ *Vmarlany@yahoo.co.id
}

\begin{abstract}
(Title: Japanese Vocabulary Acquisition through Anime: A Case Study on Dwimeilinda) This study attempted to investigate the influence of watching anime on Japanese vocabulary acquisition from Dwimeilinda. The study used a mixed-method. There are three collection data in this study; the first data is the interview; the second is observation; the last is the aural test. There are two questions from this study: first, how did she acquire the vocabulary through anime? Second. How is the influence of watching anime on her Japanese vocabulary acquisition? The results showing there are some strategies that she uses in acquiring Japanese vocabulary. First repetition, second cognate and third is mind mapping. The study also found that watching anime can influence her phonological vocabulary knowledge and daily expression.
\end{abstract}

\section{Keywords: Vocabulary acquisition, Japanese Vocabulary, Anime}

\section{INTRODUCTION}

The easy access to technology and media has made everything easy. It impacts on exposure to foreign cultures in Indonesia. In this case, the foreign culture from overseas can enter through any method such as media, and it can be easily accepted by society. For instance: Japanese culture, such as Anime. Anime is the term for Japanese animation. What makes this animation is unique and attractive is their style of drawing, it vivid and colourful graphics, vibrant characters and the medium brings works in a wide range of genres and themes such as romance, action, mystery, horror and fantasy, etc.

The uniqueness from anime can "enchant" people who watch it. As states by Obrien, the Japanese animation is gradually becoming more accepted among youths and has made its way to popular culture in the world (Obrien: 2012). Through this media, the exposure of language become common phenomena for some people. They are not just learning the culture but also the language. They learn about some words implicitly, but it doesn't mean they are fluently on the language. We call these phenomena as incidental learning. The incidental learning according to Schmitt is learning by subconscious effort. Incidental learning is accidental or unplanned learning that does not involve the intention to learn or analyze language, an explanation that might include implicit learning in a psychological sense (Kerka in Samira: 2014)

Incidental learning takes place outside the formal teaching and learning environment. That's what happens when we learn something new from watching television, reading books, talking with friends, playing video games or, as many language students do, travelling to other countries and surrounding ourselves with that language. It happens in many ways: through observation, repetition, social interaction, and problem-solving (Sandra: 2000). Incidental learning always takes place in the context of other activities or experiences. For example, playing video games in other languages. In this case, the main activity is playing games; learning 
vocabulary is a useful by-product of enjoying the game (Samira : 2014).

Incidental Vocabulary Learning motivates learners for extensive reading. It involves learners' ability to guess the meaning of new words from the contextual clues. Incidental learning occurs more particularly through extensive reading in input-rich environments. However, not all incidental learning occurs by extensive reading. Incidental learning occurs by listening.

There are many studies investigated the incidental learning of language. A study from Wilde (2017) showing there is significant impact between the exposure of language from some media and the English Proficiency. The study explored English proficiency in term of vocabulary of $11^{\text {th }}$ years old children from Europe that has not been received formal English. There are some instruments used in the study such as questionnaire and test of proficiency. The study shows that children can perform the task of A2 level, moreover the study also shows that children learn English from the input they receive through different media (especially gaming and computer use). Meanwhile, the study just focuses on the impact of exposure of the language, there is no detail description of the process or the way they acquire the language, this study uses a quantitative method.

Another study from Ashcroft (2018) showing there is significant impact of watching movie with subtitle towards the vocabulary. This study explored the impact of watching movies toward recalling some words from movies. The effect of viewing subtitle movies increases their recall toward words, the result indicated that there is significant positive result from audiovisual and viewing subtitle movie. This study uses a quantitative method with the test as an instrument. However, this study only explored pre-test and post-test of the subtitle exposure. In other words, we can call it as an experiment rather than the incidental vocabulary acquisition
Moreover, a study from Pavia (2019) showing there is a significant effect of listening music towards the acquisition of vocabulary. This study investigated learning of three vocabulary knowledge dimensions (spoken-form recognition, form-meaning connection, and collocation recognition) by listening to two songs. The result indicated that listening to music has contribution to gain the vocabulary, repeated listening the music has a significant effect to gain the vocabulary, and the frequency of exposure has positively affected learning gain.

From the previous study that had been conducted and explained above we knew that there is still the gap that has not been filled in the study, the present study tries to explored the acquisition of language through incidental learning, a little study exploring how their effect on phonological vocabulary and the impact of the use for daily expression. Moreover, little study also explored about incidental vocabulary acquisition through anime. moreover, the study about incidental learning through anime is still interesting to be explored since the anime has a wide scope of young people in Indonesia. The present study tries to explore and fill the gap of study from the previous research that had already been done. The study will be used mix method and some instruments to gather the data such as interview, aural vocabulary test, and observation.

Based on the explanation above, this study attempted to investigate the influence of anime on the development of Japanese vocabulary acquisition. Furthermore, the participant of this study is one of the college students at State Islamic University of Jakarta her name is Dwimeilinda, she likes watching anime, and from anime she acquires Japanese Vocabulary. For those stated reasons, the researchers try to investigate her Japanese vocabulary acquisition.

Importantly, the researchers focus on four research questions, including (1) How did she acquire Japanese vocabulary 
through anime? (2) How does the influence of watching anime on the acquisition of Japanese vocabulary? and (3) How does the influence of watching anime on the acquisition of Japanese vocabulary reflected through her daily speech? (4) How does the influence of watching anime on the acquisition of Japanese vocabulary through her understanding the basic Japanese vocabulary?

\section{RESEARCH METHODOLOGY}

This study used the mixed method both qualitative and quantitative with interview, observation and aural test as procedure of data collection

\section{Participant of Research}

The participant of research in this research is a college student. The participant hobby is watching anime (Japanese animation). The participant didn't learn Japanese in formal setting. This study tries to discover the influence watching anime on her Japanese vocabulary acquisition.

\section{Procedure of Data Collection}

\section{Observation}

During the research, the researchers observe the participant on her daily activities and try to look at the Japanese expressions that she uses. The time of the observation is only for about two weeks since this research started. Gray (2009) defined Observation as a type of qualitative research method which not only included participant observation, but also covering ethnography and research work in the field. In observational research design, several research sites involved. Observation data can be integrated as aids or confirm research. Robert (2000) define observation is a systematic data collection approach. Researchers use all their senses to examine people in natural environments or situations that occur naturally.
Observation of field settings involves: prolonged involvement in social settings or situations.

\section{Interview}

This data will be obtained by using open ended interview. Open ended interview (unstructured) show that, unlike structured interviews, this kind of interview is an open situation where flexibility and freedom is offered to both parties (ie interviewer and interviewee), in terms of planning, implementation and set content and interview questions (Gubrium \& Holstein in Alshenqeeti : 2014).To do an interview and to gather the data more effectively, recording interviews considered the right choice but sometimes the problem of controversy between researchers and respondents. Hand written notes during the interview are relatively unreliable, and researchers might lose a few important points. Recording Interviews make it easier for researchers to focus on interview content and verbal instructions and as such allows transcriptionists to produce "verbatim transcripts" from the interview (Jamshed : 2014). The present study will be used recording and will be transcribed it carefully.

\section{Aural Vocabulary Test}

According to Nation (2001), knowing a word refers to knowing what the word sounds like (its spoken form) or looks like (its written form) and its meaning. Hence, students need to connect the form (written or oral) of a word and its meaning. It can be assumed that there may be differences in written and vocabulary knowledge form of spoken words. as is often the case with some people who learn language, where a word can be understood when it heard, but not when it seen. Therefore, the relationship between the spoken form and the meaning also needs to be assessed in a measure test. 
The aural test can be taken by using the tools. However, there seems to be a little tools to test the spoken words. For Japanese language learner. Since the tools is limited the test of the present study will be used the website as the tools to measure Japanese vocabulary. A new aural vocabulary size test, called Aural Lex has recently been developed. It is a computerdelivered Yes/No test, which is comparable to X_Lex (written version). Test-takers are presented with 120 words one by one and required to indicate whether they know each word. (Atshusi : 2008)

Through the test of aural test the researcher will know about vocabulary knowledge that participant has. Aural test is the test for vocabulary phonology (sounds).In this research the participant will be tested to hear Japanese vocabulary from website, and the participant will guess the right answer of the meaning from that vocabulary.

\section{RESULT AND DISCUSSION}

\section{A. Strategies of Acquiring Japanese Vocabulary Through Anime}

Based on the interview the participant states that she never uses the strategies to learn the vocabulary. It can be concluded that participant learn the vocabulary incidentally, Elis states that incidental vocabulary acquisition is the vocabulary that acquire from non-formal activities outside classroom.

\section{Repetition}

Repetition is central to incidental vocabulary learning. The seminal studies about learning vocabulary through context show that words are gradually learned through repeated encounters in context. Vocabulary knowledge can be obtained each time words are found during reading or listening, and through several meetings they eventually become known. So the words that appear most often in a language tend to have the greatest opportunity to be learned incidentally inany chance
(Webb.S : 2014). Refers to that theory, from interview we can see that she usually watching more than one times of one series anime. She states that she enjoys rewatching it.

Virgi: berapa kali nonton anime dalam sehari?

Dwimeilinda: Biasanya satu seri anime dalam sehari. Dan bisa lebih kalau misalnya ngulang seri yang seru (interview 26-12-2018)

Virgi: Bagaimana caranya bisa tahu arti kata kata di anime?

Dwimeilinda: karena banyak nonton anime biasanya ada kata kata yang memang umum ada di anime dan sering didengar, kaya kata arigato, gomen, sensei, senpai, tadaima, itadakimasu. (interview 26-122018)

Repetition occurred when the words repeated frequently in reading or listening. And learner acquires the new vocabulary from that repetition. From the data above we know that she acquires the vocabulary because the repetition of the words from anime.

Virgi : Jenis kata apa yang sering muncul di anime ? dan paling gampang di ingat? Misalnya berdasarkan (pronoun, noun, adjective, adverb, verb)?.

Dwimeilinda: banyak sih kata kata yang aku inget. Kata yang sering muncul itu biasanya kata ("watashi/boku/ore" artinya saya). (kanojo artinya dia perempuan.). (sinde artinya mati). (hanning artinya pelaku). (oyoge artinya sedang berenang), (obachan artinya nenek), (onnichan artinya kakak). (otoshang artinya bapak) . (bako artinya tas), (keitni" artinya hp), (mizu” artinya "air) (toire artinya toilet) artinya, (ashita artinya tomorrow). Ada lagi (ohayo gozaimasu" artinya selamat pagi), (arigato gozaimashu artinya thankyou) (itadakimasu artinya selamat makan), (sugoi artinya keren), (baka artinya bodoh). 
The repetition kind of words such as noun, pronoun also can help learner to acquire vocabulary. From the data above the participant said that she can remember many words from anime. it can be classified in basic words such as (pronoun,verb,noun. adjective) and phrase for greeting expression such as "ohayo gozaimasu"

Signature phrases (special phrase) also contributing in the process of acquiring vocabulary, in this terms signature phrase is the phrase that usually appears repeatedly in anime that become characteristics which identical from that anime.

Virgi: Apa ada kata kata atau frase yang biasanya muncul jadi ciri khas didalam anime? dan kata kata atau frase tersebut bisa diingat dan jadi tambahan daftar kosa kata? (10-11-2019)

Virgi : Bagaimana frase atau kata tersebut muncul dalam anime? apa dengan di ucapkan oleh karakter atau dengan cara lain? (10-11-2019)

Dwimeilinda : Ya, ada di conan biasanya muncul di opening, di episode special atau di movienya. Conan biasanya ngomong "Shinjitsu wa itsumo hisotsu"

Artinya kebenaran selalu hanya ada satu. (10-11-2019)

The repetition from the signature phrase can be one of the tools and the way in acquiring the new vocabulary. The data above showing that the participant acquiring new phrase from the signature words in anime (Conan) from repeated signature phrase that usually appear in the opening of special episode or movie in Conan is "Shinjitsu wa itsumo hisotsu" means "there is always only one truth". As it states in the concept of vocabulary acquisition that the more we experienced the words the more we acquire.

\section{Mind Mapping}

Mind mapping is a technique used to produce, organize, and presented ideas and thoughts, and to learn and organize new information. Mind maping is usually created around certain concepts or ideas that are presented visually as the main key element.Mind maps can be an effective tool in learning words and vocabulary expressions by making non-linear connections. Language is used whenever and wherever possible. Vocabulary is the root of everything that involves the use of language, such as writing, advertising, publishing, and daily communication. Mind Maps is a technique that utilizes educational thinking, which allows students to build their own knowledge and understand by presenting many ideas visually, taking full advantages of images, symbols, text notes and colors (Mei li: 2010).

In the concept of vocabulary learning, there are four pattern of mind mapping in vocabulary learning that can enhance vocabulary. Such as: pattern of similar spelling, pattern of categorization, pattern of synonyms, and pattern of free association.

In pattern of categorization, many vocabularies can be arranged by category, For example, the word "clothes" can be connected to different categorization, such as "clothes", "laundry" and "accessories", and from each categorization, more related words and ideas can be linked, Grouping such as knowledge by topic can help students rationalize their knowledge cognitive structure and hence memorizing and maintaining easier vocabulary.

In this study, the participant stated that she acquired some words from the repetition of the words that often repeated in certain kind of genre in anime, for example: when she watches genre mystery. She acquired the new vocabulary from those genres.

"biasanya kalau aku suka sama genre tertentu ada kata yang sering didenger di 
Izumi, Volume 8 No 2, 2019

e-ISSN: 2502-3535 p-ISSN: 2338-249X

Tersedia online di http://ejournal.undip.ac.id/index.php/izumi

genre itu. Misalnya kalau di genre mystery di conan banyak kata yang sering di ulang jadi aku tahu kata kata itu, kaya kata Jiken artinya kasus, dorogo artinya maling, kasatsu artinya polisi. (interview 26-122018)

Furthermore, she also stated that she did mind mapping incidentally, when she categorized the words into genre of anime.

Kata ini misalnya ada digenre yang bisanya perang, atau kata ini biasanya keluar di genre misteri. Ya kaya film conan tadi (26-12-2018).

Moreover, it seems to indicated that the pictures also can help the learner to help her doing mind mapping. Picture from anime is powerful as tools of expression. We can understand the outline of story from anime through the picture. Abott (2010) stated thatManga or anime convey the emotion from their exaggerated facial expression. For instance: when the character from anime is angry. We can understand that from their facial expression.

Virgi : Apa gambar bisa berpengaruh terhadap pemerolehan kosa kata? Misalnya kalau lihat expresi marah ada kata (kasar) tertentu yang diucapkan oleh karakter anime?

Dwimeilinda: Ya, ada dan ngaruh. Kalau lagi marah biasanya di anime ngomongnya" bakayaro " atau "baka" artinya "bodoh" dan kalau lagi expresi senang biasanya karakter ngomong " yukata" artinya "syukurlah".

From the statement above it can be seen mind mapping also can be doing through the picture, facial expression from anime can be indicated on one words from character in anime. When characters angry the words that identical and usually characters say is " Baka" means"stupid" (adjective). Then when characters showing the happy facial expression the word that character usually say is " yokatta" means " it was good" (adjective).

\section{Link to Cognates}

Cognates are words that have the similar spelling, pronunciation, and meaning in two languages ( August. Et al in Ajayi 2018). Cognate languages and words have the same origin, or are related and in some way similar for instance: father in English Simmilar with vater in Germany. Study showing there is benefit from cognates with the proficiency of language, in the study teaching Spanish to English, there is significant positive result for Spanish student who learn English, the cognate can increase their vocabulary knowledge (Solak : 2012).

Many cognate studies attempt to explain how cognates facilitate L2 vocabulary activation, reading and listening understanding in L2 between the same family languages as English and Spanish. However, in recent years the number of cognates among languages such as English and Japanese or English and Turkish is starting to attract attention. In the study from Solak Showing there is positive results of this study indicate that students who use cognate-based material have better results at reading and listening comprehension and language use compared to students who use non-cognate based material. It can be concluded that cognate-based material mediates listening and reading comprehension and use of language in English learner for Turkey language learner. (Solak:2012) From this research it can be concluded that the cognate can be benefit for language learner.

In this case the present study showing that the participant states in her interview that there are some words in anime that similar with English words. She knows that meaning of that word because the similarities from another words.

Dwimeilinda: Ya ada kata memang yang mirip bahasa inggris dan biasanya tahu itu artinya apa karena mirip. Misalnya, terebi $=$ Television atau, kaato $=$ card, Chansu=Chance (Interview 4-01-2019) 
From the data above we can conclude that there are some strategies that she uses in acquiring vocabulary. The first strategies is repetition, when she repeated certain kind of genre from anime then she acquire the new vocabulary that repeated frequently from those genre. Secondly is mind mapping, she categorized the words from genre in anime. Thirdly is linking to cognates, She knows the meaning of the words because the similarities from another words in different language.

From the statement above, the word frequency is also the key to acquire the vocabulary, the more we experienced the words the more we acquire. The frequency of exposure is the key for people to acquire the vocabulary. As states by Schmitt words are not instantaneously acquired, at least not for adult second language learners. Rather, they are gradually learned over a period of time from numerous exposures. This incremental nature of vocabulary acquisition manifests itself. Moreover, the fact that she has been watching anime for around 6 years also has the contribution to her Japanese Vocabulary acquisition.

\section{B. The influence of Watching Anime to her Phonological Vocabulary knowledge}

From the interview the participant states that she knows the vocabulary from hearing it and she knows the meaning of vocabulary, but she cannot write it in Japanese letter. Even though she has been learned Japanese letter, but she didn't master it. According to Milton it calls as phonological vocabulary knowledge. This occurs due to the understanding of the word without knowing the written text from those words. Measuring word knowledge in terms of how a word sounds is hard, Milton states that this kind of acquisition just only used by several cases for example the use of vocabulary for people who visit abroad, and they speak or hear the words without knowing how to write it.

From those explanations, in the context of the influencing the anime on Japanese vocabulary acquisition, the participant just acquire vocabulary from listening, in this case the researcher will look the knowledge of vocabulary from the participant used the online aural test. This test is to recognize the sounds of word from listening, and participant will choose the meaning of that word. The purpose is to know the influence of exposure listening anime on her acquisition Japanese vocabulary, the vocabulary that will be tested is just some basic Japanese vocabulary. The test will be conducted using the aural test from the website: https://www.nhk.or.jp/lesson/english/vocab ulary/quiz/

There are 48 cards with 3 test vocabularies of each card, hence the total vocabularies on the test is 144 . If all the questions on card are correct the card will be marked by Sakura flower. From the test, the result showing that the participant got 34 cards correct and 14 cards incorrect answer. See index 1.1.

Here is the data of 14 incorrect cards. The data bellow showing the incorrect answer from test.

\begin{tabular}{cc}
\hline Number of card & Total of incorrect answer \\
\hline 9 & 1 \\
10 & 1 \\
11 & 1 \\
13 & 1 \\
14 & 1 \\
18 & 1 \\
21 & 2 \\
23 & 1 \\
24 & 1 \\
25 & 1 \\
26 & 1 \\
36 & 1 \\
40 & 1 \\
47 & 1 \\
\hline Total & $\mathbf{1 5}$ \\
\hline
\end{tabular}


Izumi, Volume 8 No 2, 2019

e-ISSN: 2502-3535 p-ISSN: 2338-249X

Tersedia online di http://ejournal.undip.ac.id/index.php/izumi

There are 15 incorrect answers of test from total test 144 . Hence, there are 129 correct answers.

Correct answer $=$ total test- incorrect answer

Correct answer $=144-15=129$

Percentage of the correct answer

$\frac{122}{144} \times 100 \%=89,58333 \%$

The data above shows that participant have the good phonological vocabulary knowledge, it can be seen from the total percentage of correct answer

Moreover, from data above the words that tested in web can be categorized as the basic vocabulary mostly tested such as (adverb of time, noun) andexpression (greeting, introduction, gratitude). However, Refers to anime that she watches the words that mostly appear in anime is basic word such as (pronoun, noun, adjective, and adverb) and expression.

\section{The Influence of Watching Anime Reflected through her Daily Expression.}

The participant also utilizes some vocabulariesin her daily expression. In this part I will explain some of the words that she usually uses based on the observation, in this observation the researcher just stated some of words that she uses frequently.

The first word that she usually used is Arigato which is means thank you in English. Here is the dialogue

\section{Data 1:}

Dwi: Kak minta wifi dong

Virgi: pakai aja masih banyak kuotanya

Dwi: hehe, arigato

The word arigato is the most frequently word that she used. This word refers to gratitude and this word also appears frequently in anime.
Then, the second word that she uses is Ojamashimasu

Dwi : Ojamashimasu

She uses that words when the cat come in to her room, the meaning of this word is Excuse me, may I come in. She uses that word to speaks to cat (means the cat speaks to her to get permission to come in to her)

\section{CONCLUSIONS}

From the research finding, It can be concluded that there are some strategies that she uses to acquiring the vocabulary such as: link to Cognate, Repetition, and Mind mapping. The first is the repetition, when she repeated certain kind of genre from anime then she acquires the new vocabulary that repeated frequently from those genres.Then, when she repeated incidentally the signature phrase (special phrase) that become characteristic or identical in particular title of anime such as in Conan. Secondly is mind mapping, she categorized the words from genre in anime, and also through the picture "the characters' facial expression" that correlated with commonly words spoken by character when they are showing particular facial expression. Thirdly is linking to cognates, she knows the meaning of the words because the similarities from another words in different language.

The word frequency is also the key to acquire the vocabulary, the more we experienced the words the more we acquire. The frequency of exposure is the key for people to acquire the vocabulary. As states by Schmitt words are not instantaneously acquired, at least not for adult second language learners. Rather, they are gradually learned over a period of time from numerous exposures. This incremental nature of vocabulary acquisition manifests itself. Moreover, the fact that she has been watching anime for around 6 years also has the contribution to her Japanese Vocabulary acquisition. 
Izumi, Volume 8 No 2, 2019

e-ISSN: 2502-3535 p-ISSN: 2338-249X

Tersedia online di http://ejournal.undip.ac.id/index.php/izumi

The influence of watching anime also can be seen from her phonological Japanese knowledge. from the aural test that propose to knowing her vocabulary knowledge. she knows around 89,58333\% basic vocabulary. The influence of Anime also can be seen through some her daily expression such as arigato, ojamashimasu

\section{REFERENCES}

Ajayi, L. (2018). Using Cognates for Vocabulary Development. The TESOL Encyclopedia of English Language Teaching, First Edition.

Aschroft, R.J \& Garner Josheph. (2018) Incidental Vocabulary Learning Through Watching Movies.Australian Journal of Applied Linguistics, 1 (3), 135-147 https://dx.doi.org/10.29140/ajal.v1n $\underline{3.89}$

Alsenqeeti. H. (2014). Interview as data critical Method. Newcastle upon Tyne, United Kingdom. doi:10.5430/elr.v3n1p39 URL: http://dx.doi.org/10.5430/elr.v3n1p $\underline{39}$

Atshusi, M \& Taiko, S. A Comparison of Aural and Written Vocabulary Size of Japanese EFL University Learners.Language Education \& Technology, 45. pp. 35-52

Cook, V. (2008). Second language learning and language teaching. London: Hodder Education.

Gray DE. (2009). Doing Research in the Real World. 2nd ed. Thousand Oaks, California: Sage Publications.

Gu, P, Y. (2015) Vocabulary Guessing Strategies. Retrieved on : https://www.researchgate.net/public ation/299727103 Vocabulary Gue ssing_Strategies

Huang,S \& Eslami,Z.(2013). The Use of Dictionary and Contextual Guessing Strategies for Vocabulary Learning by AdvancedEnglishLanguage Learners.3(3). Canadian Center of Science Education.

Hutton T.L. (2008) Three tiers of vocabulary and education, Superduperhandyhandsout.

Jamshed, Sazia. ( 2017). Qualiative Research Mathod Interviewing and Observaton. Department of Pharmacy Practice, Kulliyyah of Pharmacy, International Islamic University Malaysia, Kuantan Campus, Pahang, Malaysia. DOI:10.4103/0976-0105.141942

Milton, J. (2009).Measuring second language vocabulary acquisition.UK: British Library Cataloguing in Publication Data

Mei, L \& Kun, Y. (2010). Using Mind Maps as a Strategy for Vocabulary Acquisition in Chinese Universities.Faculty of Foreign Languages Beijing Normal University at Zhuhai.

Otwinowska, A \& Szewczyk.J.M. (2017) The more similar the better? Factors in learning cognates, false cognates and non-cognatewords. International Journal of Bilingual Education and Bilingualism http://dx.doi.org/10.1080/13670050 .2017 .1325834 
Izumi, Volume 8 No 2, 2019

e-ISSN: 2502-3535 p-ISSN: 2338-249X

Tersedia online di http://ejournal.undip.ac.id/index.php/izumi

O’Brien, C. (2012). Can Americans Make Anime? Escapist. Retrieved from: http:/www.escapistmagazine.com/ articles/view/features/9829-CanAmericans-Make- Anime

Pavia. N \& Webb.S. (2019). Incidental Vocabulary Learning Through Listening to songs, Studies in Second Language Acquisition, 2019, page 1 of 24 doi: $10.1017 / \mathrm{S} 0272263119000020$

Richards, J. C., \& Renandya,W.A. (2002). Methodology in language teaching. (An anthology of currentpractice). Cambridge: Cambridge University Press.

Saidi.L.G. \&Ansaldo. A.i. Second Language word learning through repetition and imitation: Functional Networks as a Function of Learning Phase and Language Distance.September 2017. 11 (463).
Solak, H.G \& Cakir. Abdul. (2012). Cognate based language teaching and material development. Procedia - Social and Behavioral Sciences 46 $431-434$

Webb. S.(2014). Repetition in incidental vocabulary learning. Encyclopedia of Applied Linguist.

Wilde.D.V \& Ecyckmans. J. Game on! Young learners' incidental language learning of English prior to instruction. Department of English Studies, Faculty of Pedagogy and Fine Arts, Adam Mickiewicz University, Kalisz SSLLT 7 (4). 2017. 673-694 doi: 10.14746/ssllt.2017.7.4.6 http://pressto.amu.edu.pl/index.php /ssll 

Izumi, Volume 8 No 2, 2019

e-ISSN: 2502-3535 p-ISSN: 2338-249X

Tersedia online di http://ejournal.undip.ac.id/index.php/izumi

\title{
Apologies In "Whatsapp" Produced By Japanese Department Student Of Universitas Muhammadiyah Yogyakarta
}

\author{
Azizia Freda Savana*, Rosi Rosiah \\ Universitas Muhammadiyah Yogyakarta \\ *aziziafreda@umy.ac.id
}

\begin{abstract}
(Title: Apologies In "Whatsapp" Produced By Japanese Department Student Of Universitas Muhammadiyah Yogyakarta) This paper discusses an apology in Whatsapp by Japanese Department Students of Universitas Muhammadiyah Yogyakarta in several situations use semantic formula. In era digital, Many of them always deliver their message to Whatsapp. They use Whatsapp for sharing information, expressing gratitude and apologies to their friends and teachers. Expressing apologies via Whatsapp is different from expressing it directly. Writing using Whatsapp will be more creative by using emoji or kaomoji based on the situations. Besides that, they usually abbreviate their writing on Whatsapp. The purpose of this research is to know how Japanese Department Students of Universitas Muhammadiyah Yogyakarta expressing apologize via Whatsapp in several situations to the teacher, seniors, and friends. Do they use emoji or kaomoji and how they write an apologizing with the Teacher, Seniors, and Friend?. This research uses a descriptive method with qualitative approaches since analyzed descriptively with the qualitative method. The method of analysis used the semantic formula to classify apologies based on the situation. The result of this research is the student's tendency most of them use In-speech act instruction designation (apology content, appreciation, etc.) and they not so using emoji to express apologies to teachers.
\end{abstract}

Keywords: Apologies; Whatsapp; Semantic Formula

\section{INTRODUCTION}

Learners of Japanese language must know the use of the language correctly by understanding the culture. Understanding the culture of Japanese society will be easier to achieve by comparing our own culture so that it can be clearly seen the general differences and similarities of cultures objectively. A lack of understanding of culture can cause a problem in communication, included in the apology. A culture of apologies between Japanese and Indonesian are different. There are cultural differences in apology in terms of apologize timing (when apologies are made) and what kind of apology should be (how appropriate content and apology in a situation), (Spencer-Oatey et al., 2004). Before knowing the culture of apologizing Japanese, students must know characteristic in advance the culture of Indonesian's apologies to be easier to learn Japanese. Therefore, this research only focuses on apologies produce by Japanese Department Student of Universitas Yogyakarta.

Ohama (2010) has been researched about apologizing strategy using the semantic formula by mobile e-mail to senior and college friends. The research used two situations are group work and travelling plan. The result based on two situations is:

a. The tendency apologizing using semantic formula is Speech Act 
Indication Expression and Promises Of Self Control.

b. When apologizing to close friends, they used polite language than casual language.

c. Emojii and kaomoji are used in traveling plan situations than group work situation.

d. Apology appropriate in mobile email shouldn't used emoji and kaomoji.

Previous research used two situations (group work and traveling plan) based on semantic formula to senior and close friends by mobile email, while this research used three situations (late to collect assignment, lost the senior's book, and cancel a promise to meet) based on semantic formula to teacher, senior and close friends. This research also used Whatsapp application rather than a mobile email.

There are various ways of expressing apologies, direct or indirect. One of the expressions of indirect requests is through Whatsapp application on smartphones. In the digital era, Many of Japanese Department Student of Universitas Muhammadiyah Yogyakarta always deliver their message by Whatsapp. They use Whatsapp for sharing information, expressing gratitude and apologies to their friends and teachers. Texting by using Whatsapp will be more creative by using emoji or kaomoji based on the situations. This research is aimed to know how they are expressing apologize with Indonesian text using Whatsapp in several situation to the teachers, seniors, and friends, and do they use emoji or kaomoji in apologizing using Whatsapp.

Leech politeness is concerned with the participant's ability in a social interaction to relative harmony (Leech \& Oka, 1993) There are six maxims of the politness principles, those are:

a. The Tact Maxim

The tact maxim is concern to minimizing cost and maximizing benefit. Make the loss of others as little as possible and make other people's profits as big as possible.

b. The Generosity Maxim

The generosity maxim is about minimizing benefit and maximizing cost. Make the benefit minimizing to self and make the cost maximizing to self.

c. The Approbation Maxim In Expression and assertiveness. Minimizing dispraise of other and maximizing praise of other

d. The Modesty Maxim In Expression and assertiveness. Minimizing praise of self and maximizing dispraise of self.

e. The Agreement Maxim

The greement maxim is about keep the disagreement between self and others as little as possible, make maximize agreement between self and others.

f. The Simpathy Maxim

The sympathy maxim is about minimize antipathy between self and other, maximize sympathy between self and other.

While (Brown, Levinson, \& Levinson, 1987) distinguish politeness strategies on the basis of the illocutionary transparency by which face threatening acts "(FTA) are carried out. The organizing principle for their polite theory comes from the idea that some acts are intrinsically threatening to face and thus require softening (1987: 24). This means, to Brown and Levinson, that face is the essential element of politeness. To be polite is to be face-caring ( $\mathrm{Gu}, 1990)$. In addition, politeness theory can be used to protect the hearer's face or self-images through various strategies (Pitts, Fowler, Fisher, \& Smith, 2014). Among the speech acts we employ in daily communication, apology is one of the most frequently used. Apology is a face- threatening act that requires the speaker to admit their 
responsibility for some behavior (or failure to carry out some behavior) that has proved costly to the hearer (Brown et al., 1987). It aims at maintaining the harmony relationship between the speaker and the hearer. To apologize is to act politely, both in vernacular sense and in more technical sense of paying attention to the addressee's face needs (Brown et al., 1987). Apology can be positive and also negative depend on where we see. It can be negative because it is focused on the damage caused by the offence that done by the speaker to the hearer without focussing on S's face when apologizing. Also it can be positive because in this point, we can see the function of apology is to repair S's mistakes to the addressee. So we can see the S's respect and S try to maintenance the better relationship with the addressee. By apologizing, the speaker recognizes the fact that a violation of a social norm has been committed and admitted to the fact that $\mathrm{s} / \mathrm{he}$ is at least partially involved in its cause. Hence, by their very nature, apologies involve loss of face for both interlocutors. According to Leech's classification of illocutionary functions (Leech \& Oka, 1993), apologies can be assigned to the convivial speech act type, in which the illocutionary goal similar to the social goal. In the case of apologies, it is the goal of keeping harmony between speaker and hearer, which makes them inherently polite. (Sw, 2014).

The use of politeness strategies depen on three social variables (Brown et al., 1987): a) the social distance; b) difference between the power of the speaker and the listener; c) The cultural ranking of the speech acts (how threatening or dangerous it is in a specific culture).

\section{Apology Strategy (Semantic} Formula) Blum-Kulka et (Ohama, Sakamoto, \& Sakuraba, 2010) There are semantic formula of apology strategy: a. Speech Act Indication Expression (Apology substance, gratitude, etc) Example: I'm Sorry, Thank you for your attention, etc.

b. Recognition Of Responsibility Example: That's all my fault.

c. Explanation and Reason Example: Because of traffic, I'm late.

d. Offer For Compensation Example: I will buy a new one and return it

e. Promises Of Self Control Example: I will be more carefull

Indonesian express their apology used several strategies, (Choer, 2010) such as addressed, phatic and interjection. but in communication speakers use several strategies. They can use one strategy with another to express apology. Mostly, they used IFID ${ }^{1}$ (Aisatsu) followed by addressed like "maafkan saya bu". But when speakers know toward whom they apology, they will more pay attention their politeness. They will use formal situation when apologizing to the higher power and position like their lecturer, and they usually use informal when apologozing to their friends which is in same power or having close social distance. They mostly add phatic or interjection to express their apology in informal situation like "wah maaf ya hehe".

Indonesian students has been familiar with apology expression. When Indonesian apologizing, they always using a simple word like "maaf" or sometime they say in English "eh, sorry ya" or just "sorry" which isn't reveal the explicit meaning when the speaker asking for apologizing. (Aziz \& Lukman, n.d.)

The Indonesian students used IFID (Aisatsu) when they are asking for apology.

\footnotetext{
${ }^{1}$ IFID (Illocutionary force indicating device) is an aspect of linguistic or element that indicating the utterance is made certain illocutionary force, or else that constitutes the performance of a certain illocutionary act.
} 
They say "sorry" followed by addressing to make sure their apology is addressed to whom. Besides that, they also can accept their fault by giving an explaining the situation why they did the mistake. Generally, they offer to fix it. They promise not do the mistake again and hope that the hearer will be convinced with their apology. But they also used phatic and interjection. For all the strategies that used by Indonesian students, it can be called that Indonesian students have a good politeness when they pologizing. They realize their fault and accept their fault by giving a repair. $(\mathrm{Sw}, 2014)$

Whatssapp is an instant messaging application in smartphone which practically can be used to write and to send message to the to others. (Barhoumi, 2015). Whatsapp (from the English phrase "whats up?" meaning "whats news", It allows users to exchange images, videos, and audio, or written messages using their internet connection. Whatsapp has positioned itself as a superior alternative to SMS messaging, which can be very expensive when used in foreign countries due to roaming charge; whatsapp, in contrast, relies on the active wifi network. Not only is Whatsapp often more costeffective than SMS (Short Message Service), but it also facilitates large group conversations, something that is difficult through SMS. While freely sharing information over the internet is common to many social networks, and other public messaging services, such as Twitter, exist, the private nature of the Whatsapp network makes it rather unique. Not only its registration done exclusively through one's phone number, but the smartphone is the primary interface for sending and receiving message (Rosenfeld, Sina, Sarne, Avidov, \& Kraus, 2018) The feature of Whatsapp Instant Messaging (Whatssapp.com) are: a) Text (Simple, Reliable Messaging); b) Group Chat; c) Whatsapp voice and video call; d) End to End Encryption; e) Share photo and videos; f) Document sharing; and g) Voice Message.

\section{METHOD}

This research uses the descriptive method with qualitative approaches which analysis is done descriptively with the qualitative method. (Sutedi, 2009), the qualitative approach is research that approaches data, not in the form of numbers and does not need to be processed using statistical methods. The research data could be in the form of sentences, recordings, or other forms. While Descriptive method is a research that is conducted to describes a phenomenon that occurs today by using scientific procedures to answer the problem. The method of analysis used Apology Strategy (Semantic Formula) Blum Kulka et (Ohama, Sakamoto, \& Sakuraba, 2010) to classify apologies based on the situation. As samples of this research are 15 students on the Japanese Department Of Universitas Muhammadiyah Yogyakarta.

This research procedure is as follow: a) Collecting of data in Whatsapp based on three situations; b) Classify the data in three situations based on semantic formula; c) Analyzed the data based on semantic formula and speech act and the politeness of the language used; d) Analyzed data based on the use of emojis; e) Conclude.

\section{RESULT AND DISCUSSION}

There are three situations to get data in this research. The situations are:

1. Apologies to the teacher because of late to collect assignment

2. Apologies to senior because of lost the senior's book

3. Apologies to a friend because of cancel a promise to meet

According to the situations, we analyzed the data based on Blum-Kulka's semantic 
Izumi, Volume 8 No 2, 2019

e-ISSN: 2502-3535 p-ISSN: 2338-249X

Tersedia online di http://ejournal.undip.ac.id/index.php/izumi

formula. The data analysis of apologies in

Whatsapp instant Messaging are:

Table 1. Data of apologies in Whatsapp

\begin{tabular}{|c|c|c|c|}
\hline Apology Strategies & Situation 1 & Situation 2 & Situation 3 \\
\hline $\begin{array}{l}\text { Speech Act } \\
\text { Indication Expression }\end{array}$ & $\begin{array}{l}\text { Maaf, mohon maaf, } \\
\text { Terima kasih }\end{array}$ & $\begin{array}{l}\text { Maaf, mohon maaf, maap, } \\
\text { maaf banget, terima kasih, }\end{array}$ & Maap, maaf, sorry \\
\hline $\begin{array}{l}\text { Recognition Of } \\
\text { Responsibility }\end{array}$ & $\begin{array}{l}\text { Saya memang murid } \\
\text { yang tidak tepat waktu } \\
\text { selalu membuat sensei } \\
\text { kecewa }\end{array}$ & $\begin{array}{l}\text { kak saya teledor, karena } \\
\text { kelalaian saya, }\end{array}$ & \\
\hline $\begin{array}{l}\text { Explanation and } \\
\text { Reason }\end{array}$ & $\begin{array}{l}\text { Ban motor bocor, } \\
\text { Masalah pada laptop, } \\
\text { kurang informasi batas } \\
\text { waktu pengumpulan }\end{array}$ & & $\begin{array}{l}\text { Ada acara organisasi, } \\
\text { keperluan mendadak }\end{array}$ \\
\hline $\begin{array}{l}\text { Offer For } \\
\text { Compensation }\end{array}$ & $\begin{array}{l}\text { Besok masih bisa tidak } \\
\text { mengumpulkannya? }\end{array}$ & $\begin{array}{l}\text { Nanti saya ganti buku yang } \\
\text { baru }\end{array}$ & $\begin{array}{l}\text { Gimana kalau ganti } \\
\text { hari esok?, }\end{array}$ \\
\hline $\begin{array}{l}\text { Promises Of Self } \\
\text { Control }\end{array}$ & $\begin{array}{l}\text { Ke depannya tidak saya } \\
\text { ulangi. }\end{array}$ & & $\begin{array}{l}\text { Nanti kalo masih } \\
\text { nyukup waktunya aku } \\
\text { nyusul. }\end{array}$ \\
\hline
\end{tabular}

The data analysis shows that in the situation 1 used five of apologies strategy, the situation 2 only used three of apologies strategy (Speech Act Indication Expression, Recognition Of Responsibility, and Offer For Compensation), and the situation 3 used four of apologies strategy (Speech Act Indication Expression, Explanation and Reason, Offer For Compensation, and Promises Of Self Control).

According to the analysis data, there is a frequency usage of apologies strategy form 15 students on the Japanese Department of Universitas Muhammadiyah Yogyakarta.

The graphic of the situation 1 shows that speech act indication expression is $100 \%$, Recognition of responsibility is $6.7 \%$, explanation and reason is $66.7 \%$, Offer for compensation is $13.3 \%$, and Promise of Self Control is $13.3 \%$. Situation 2 shows that speech act indication expression is $100 \%$, Recognition of responsibility is $13,3 \%$, and Offer for compensation is $73.3 \%$. Explanation and reason and Promise of Self Control are $0 \%$. The situation 3 shows that Speech Act Indication Expression is $100 \%$, Explanation and Reason is $80 \%$, Offer For Compensation is 13,3 and Promises Of
Self Control is $6.7 \%$. But, Recognition Of Responsibility is $0 \%$.

Based on the semantic formula, strategies of apology by students in every situation tend to be Speech Act Indication Expression, Explanation and Reason, and Offer for compensation.

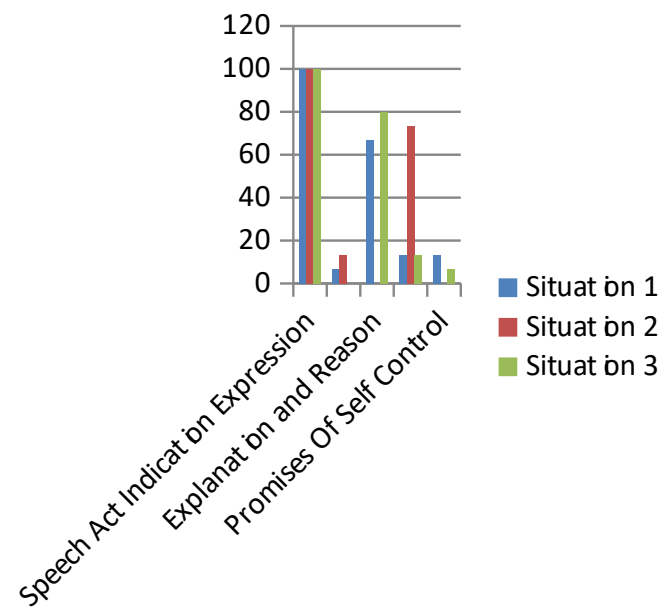

Figure 1 Frequency of apologies strategy use.

In three situations in Speech Act, Indication Expression is $100 \%$, this is because the students naturally used the word "sorry" for apologizing. Situation 1 has five apologies strategy because there's different power between speaker and 
listener. The speaker is more powerless than the listener (Teacher and Student).

They use emoji in every situation when apologizing in Whatsapp Instant Messanger. But, they don't use many emoji when apologizing to the teacher. In terms of writing, they don't abbreviate words when apologies with the teacher. But, they abbreviate words when writing apologies to seniors and friends. Although among close friends usually, they use casual language, some use polite language when expressing apologies.

\section{CONCLUSION}

The result of this research could find out how the Japanese Department Student of Universitas Muhammadiyah Yogyakarta makes apologies using Whatsapp in three situations and focus on the Indonesian language. Based on situation 1(apologies to the teacher), They used five of apologies strategy, they are Speech Act Indication Expression, Recognition Of Responsibility, Explanation and Reason, Offer for Compensation, Promises Of Self Control and don't use much emoji or abbreviate words when apologizing in Whatsapp Instant Messanger.

Situation 2 (apologies to senior) only used three of the apologies strategy (Speech Act Indication Expression, Recognition Of Responsibility, and Offer For Compensation). Situation 3 (Apologies to a friend) used four of the apologies strategy (Speech Act Indication Expression, Explanation and Reason, Offer For Compensation, Promises Of Self Control). Both of situation 2 and situation 3 used many emojis and abbreviated words when apologizing in Whatsapp Instant Messanger. Situation 1 has five apology strategies because there are differences between the power of the speaker and the listener. The speaker is more powerful than the listener (teacher and student). Moreover, the students used casual language and some used polite language when expressing apologies to close friends and seniors.

This research only focuses on the Indonesian language, and more research is needed to compare Indonesian and Japanese language, how the student makes apologies using Whatsapp Instant Messanger in several situations.

\section{ACKNOWLEDGEMENTS}

Thank you to many people who helped and supported us for this research. Firstly, we should thank Mr. Suryanto, the dean of the faculty of language education in Universitas Muhammadiyah Yogyakarta for his support. Secondly, we are thanks to Mr. Dedi Suryadi, deputy dean of academic affairs, research, and publication of the faculty of language education. for the support and feedback. We need thanks Universitas Muhammadiyah Yogyakarta, we love to work here who always support any research activity. We also thank Public Relation and Protocol Universitas Muhammadiyah Yogyakarta, Japanese Language Education department Universitas Muhammadiyah Yogyakarta who always support Azizia. Last but not least, we want to thank our family for their love, caring, and support. Thanks for understanding our crazy busy all the time and we are grateful so much to you all.

\section{REFERENCES}

Aziz, E., \& Lukman, I. (n.d.). Realisasi Penuturan Meminta Maaf dan Berterimakasih di kalangan penutur bahasa Indonesia: Sebuah Kajian Kesantunan berbahasa. Jurnal Linguistika, 13, 122-142.

Barhoumi, C. (2015). The Effectiveness of WhatsApp Mobile Learning Activities Guided by Activity Theory on Students' Knowledge Management. Contemporary Educational Technology, 6, 221-238. 
Izumi, Volume 8 No 2, 2019

e-ISSN: 2502-3535 p-ISSN: 2338-249X

Tersedia online di http://ejournal.undip.ac.id/index.php/izumi

Brown, P., Levinson, S. C., \& Levinson, S. C. (1987). Politeness: Some Universals in Language Usage. Cambridge University Press.

Choer, A. (2010). Kesantunan Berbahasa. Jakarta, Indonesia: Rineka Cipta.

Gu, Y. (1990). Politeness phenomena in modern Chinese. Journal of Pragmatics, 14(2), 237-257.

Leech, G. N., \& Oka, M. D. D. (1993). Prinsip-prinsip pragmatik. Universitas Indonesia.

Pitts, M. J., Fowler, C., Fisher, C. L., \& Smith, S. A. (2014). Politeness Strategies in Imagined Conversation Openers About Eldercare. Journal of Language and Social Psychology, 33(1), 29-48.

Rosenfeld, A., Sina, S., Sarne, D., Avidov, O., \& Kraus, S. (2018). A Study of
WhatsApp Usage Patterns and Prediction Models without Message Content. ArXiv:1802.03393 [Cs].

Sutedi, D. (2009). Penelitian Pendidikan Bahasa Jepang. Bandung: Humaniora.

Sw, A. Winda. (2014). Apologizing Strategies Realization Of Indonesian: A Case Study Of The University Of Kuningan Students. English Review : Journal Of English Education 2(2), 200208.

Ohama, Reiko., Sakamoto, S., Sakuraba, M. (2010). What kind of apology are appropriate?: an apology by mobile e-mail. Bulletin of the Department of Teaching Japanese as a Second Language, Hiroshima University, (20), 37-43. 


\title{
Budaya Permintaan Maaf Di Tempat Kerja Dalam Drama Jepang: Tinjauan Sosiolinguistik
}

\author{
Eka Marthanty Indah Lestari \\ Universitas Brawijaya \\ lestari.eka86@ub.ac.id
}

\begin{abstract}
Abstrak
Permintaan maaf merupakan tindakan di mana seseorang menyatakan penyesalan atas kesalahan yang telah dilakukan. Tata cara dalam meminta maaf berkaitan erat dengan budaya yang berlaku di suatu tempat. Secara umum, penelitian ini bertujuan untuk mendapatkan gambaran mengenai budaya permintaan maaf di tempat kerja di Jepang. Selanjutnya, secara khusus tujuan penelitian ini adalah: 1) mengidentifikasi ungkapan permintaan maaf yang digunakan di tempat kerja; 2) mengidentifikasi strategi permintaan maaf yang digunakan di tempat kerja; dan 3) menganalisis aspek-aspek yang mempengaruhi pemilihan ungkapan dan strategi permintaan maaf. Metode penelitian yang digunakan adalah kualitatif, sedangkan permasalahan penelitian ditinjau dari perspektif sosiolinguistik. Sumber data dalam penelitian ini adalah drama Jepang berjudul Haken no Hinkaku (2007). Dalam drama tersebut ditemukan 78 (tujuh puluh delapan) ungkapan permintaan maaf yang digunakan di tempat kerja. Strategi permintaan maaf yang digunakan di antaranya: 1) meminta maaf secara langsung; 2) memberikan penjelasan atau mengemukakan alasan; 3) bertanggungjawab; 4) menawarkan penggantian barang; dan 5) berjanji untuk tidak mengulangi kesalahan yang sama. Selanjutnya, aspek-aspek yang berperan dalam pemilihan ungkapan dan strategi permintaan maaf, yaitu situasi, bobot kesalahan yang diperbuat, dan status lawan bicara.
\end{abstract}

Kata kunci: permintaan maaf; ungkapan permintaan maaf; strategi permintaan maaf; sosiolinguistik.

\begin{abstract}
(Title: The Apology Culture in Workplace in The Japanese Drama: A Sociolinguistic Overview). The apology is an action in which a person states his/her regret on the mistake which he/she did. The procedures in apology are closely related to the culture which is applicable in a region. This research in general aims to understand the apology culture in the workplace of Japan. The specific objectives of this research are 1) to identify the expression of apology used in the workplace; 2) to identify the apology strategy used in the workplace; and 3) to analyze the aspects which affect choices of expression and apology strategy. The qualitative research methodology was used, while the problem of research was viewed from the perspective of sociolinguistics. Source of the data in this research is a Japanese drama entitled Haken no Hinkaku (2007). In the drama, there are 78 (seventy-eight) apology expressions used in the workplace. The apology strategies are as follows: 1) directly apologizing; 2) providing explanation or stating the reason; 3) being responsible; 4) offering replacement of the damaged goods; and 5) making a promise to not repeat the same mistake.
\end{abstract}


Izumi, Volume 8 No 2, 2019

e-ISSN: 2502-3535 p-ISSN: 2338-249X

Tersedia online di http://ejournal.undip.ac.id/index.php/izumi

Furthermore, the aspects which play role in choosing expression and apology strategy are situation, degree of the mistake which was made, and the status of interlocutors.

Keywords: apology; apology expression; apology strategy; sociolinguistics.

\section{PENDAHULUAN}

Permintaan maaf didefinisikan
sebagai tindakan kompensasi atas
kesalahan yang telah diperbuat yang melibatkan pihak yang bersalah dan pihak yang dirugikan (Bergman \& Kasper dalam Kasper \& Blum-Kulka, 1993, p. 82). Dalam permintaan maaf yang ditekankan adalah pihak yang meminta maaf telah melakukan sesuatu yang bersifat mengganggu atau merugikan oang lain serta menyesali perbuatannya dan bertanggung jawab atas hal tersebut (Aijmer, 2014, p. 81). Holmes (1990, p. 161) mengemukakan beberapa kondisi yang harus diperhatikan dalam menganalisis permintaan maaf, yaitu: 1) tindakan; 2) keyakinan bahwa tindakan yang telah dilakukan tersebut merugikan orang lain; dan 3) bentuk tanggung jawab oleh pihak yang bersalah atas tindakan yang telah dilakukan.

Tata cara dalam meminta maaf berkaitan erat dengan budaya yang berlaku di suatu tempat. Dalam budaya Jepang, permintaan maaf merupakan hal yang tidak dapat dipisahkan dari kehidupan seharihari Kondo \& Taniguchi (2008, p. 148) menyatakan bahwa orang Jepang cenderung menerima permintaan maaf dengan penjelasan yang singkat. Penjelasan yang panjang dianggap kurang pantas karena pihak yang bersalah akan terlihat seperti meminimalisir tanggung jawab. Selain itu, permintaan maaf sebaiknya diiringi dengan introspeksi diri (hansei) di mana pihak yang bersalah berjanji tidak akan mengulangi kesalahan yang sama.

Masyarakat Jepang mengenal konsep uchi (in-group) dan soto (outgroup). Ini menandakan bahwa masyarakat Jepang berorientasi pada kelompok. Menurut Tsuda (2003, p. 148) jika seorang individu berinteraksi dengan orang di luar kelompoknya, maka diharuskan untuk menunjukkan sikap formal dengan menaati norma atau etika yang berlaku (omote). Sebaliknya, ketika seorang individu berinteraksi dengan orang di dalam kelompoknya, maka individu tersebut dapat menunjukkan sikap informal yang bertentangan dengan norma atau etika yang berlaku (ura). Keempat konsep ini turut berperan dalam budaya permintaan maaf di Jepang.

Penelitian ini membahas tentang permintaan maaf di tempat kerja dalam drama Jepang. Drama yang digunakan berjudul Haken no Hinkaku (Nagumo, Sato, Shigeyama, \& Yoshino) yang tayang di NTV pada 2007 dan memperoleh rating $20,10 \%$ pada masa penayangannya. Drama ini menceritakan tentang seluk-beluk keberadaan haken di perusahaan Jepang. Haken merupakan pegawai tidak tetap yang mendapatkan pekerjaan melalui agensi di mana kontraknya berlaku selama 3 (tiga) bulan, tetapi dapat diperpanjang kembali selama perusahaan masih membutuhkan. Dalam drama ini terdapat banyak ungkapan permintaan maaf dengan konteks yang berbeda-beda, misalnya permintaan maaf antara pegawai tetap dengan pegawai tetap, antara haken dengan haken, antara haken dan pegawai tetap, dan sebagainya. Permintaan maaf yang muncul akan ditinjau dari perspektif sosiolinguistik.

Rumusan masalah yang diangkat dalam penelitian ini adalah: 1) ungkapan permintaan maaf yang digunakan di tempat kerja; 2) strategi yang digunakan ketika meminta maaf; dan 3) aspek-aspek yang mempengaruhi penggunaan ungkapan dan strategi permintaan maaf. Penelitian yang mengangkat tema permintaan maaf hingga saat ini masih sering dilakukan. Hal ini disebabkan permintaan maaf sulit untuk 